\title{
WALTER BENJAMIN E O SURREALISMO
}

Rodrigo de Negreiros Moura ${ }^{1}$ e Irenísia Torres de Oliveira ${ }^{2}$

\begin{abstract}
RESUMO
Este trabalho busca uma compreensão da relação de Walter Benjamin com o surrealismo, a partir do seu ensaio, $O$ surrealismo: o último instantâneo da inteligência europeia. Dividido em cinco tópicos, o trabalho em questão mostra como o pensador alemão analisou um dos principais movimentos vanguardistas europeu, o surrealismo. A interpretação de Benjamin é caracterizada pelos principais fatos que marcaram as primeiras décadas do século XX na Europa e, em particular, na Alemanha e está relacionada tanto com os seus ensaios posteriores como também com o próprio movimento surrealista, características essas que este texto enfatiza.
\end{abstract}

Palavras-chave: Walter Benjamin. Surrealismo. Perspectiva revolucionária. Século XX. Inteligência europeia.

\begin{abstract}
This paper seeks an understanding of the relationship of Walter Benjamin to surrealism, from his essay, Surrealism: the last snapshot of the European intelligence. Divided into five topics, the work in question shows how the German thinker considered one of the leading European avant-garde movements, Surrealism. The interpretation of Benjamin is characterized by major events that marked the early decades of the twentieth century in Europe and particularly in Germany and is related to both their later essays as well as his own surrealist movement, these characteristics that this text emphasizes.
\end{abstract}

Keywords: Walter Benjamin. Surrealism. Revolutionary perspective. Century XX. European intelligence.

As afinidades entre o pensamento de Walter Benjamin e o surrealismo são muitas. Todas elas podem se resumir, entretanto, no modo como o surrealismo questionou o mundo moderno. Aliando a crítica a uma revolta emocionada do espírito, a vanguarda francesa nos mostra, por meio de suas obras mais representativas, um horizonte de experiências mágicas possíveis dentro do cotidiano de uma cidade moderna. A partir disso, Benjamin faz uma interpretação inovadora do movimento artístico liderado por André Breton no ensaio O surrealismo: o último instantâneo da inteligência europeia, em que a análise das principais características

\footnotetext{
1 Bolsista Pibic/Cnpq e aluno de Graduação em Letras da UFC
}

2 Professora Adjunta da Universidade Federal do Ceará (UFC) 
estéticas está vinculada a uma perspectiva de revolução política. A peculiaridade dessa interpretação está diretamente relacionada à própria particularidade do pensamento benjaminiano, que está, por sua vez, fortemente ligado ao momento político por que passava a Europa nas primeiras décadas do século XX. Dessa forma, a compreensão do ensaio em questão passa, primeiramente, pelo entendimento das circunstâncias que envolviam tanto a escrita e publicação deste, como também pelo momento por que passava a própria vanguarda surrealista.

A publicação do artigo O surrealismo: o último instantâneo da inteligência europeia ocorreu em 1929 na revista Literarische Welt, um periódico semanal importante na República de Weimar. A década de vinte talvez seja o período mais definidor da trajetória intelectual de Walter Benjamin, onde a influência do marxismo e a crítica à ideologia burguesa aparecem de maneira mais relevante. Logo de início, é importante ressaltar a consolidação do regime social democrata na Alemanha tanto sobre os movimentos revolucionários da esquerda quanto sobre as tentativas de golpe da direita política devido, sobretudo, à recuperação dos danos financeiros da Primeira Guerra Mundial, o que proporcionou um aparente estado de contentamento, fazendo com que a ideologia progressista se difundisse por todo o país.O interesse de Walter Benjamin pelo marxismo, que se espalhava fortemente por toda a Europa após a Revolução Russa, ocorreu devido a suas leituras de Ernst Bloch e G. Lukács e, principalmente, ao seu relacionamento amoroso com Asja Lacis, militante comunista russa. A antipatia pelo pensamento burguês está presente desde os seus trabalhos iniciais, como a Vida dos estudantes, de 1915, mas aflora de forma mais intensa com o seu desligamento de qualquer pretensão acadêmica, ocasionado pela recusa de sua tese de livre docência em 1925, o que acentuará a sua crítica à ciência literária burguesa. Outro fato importante na vida de Benjamin é a escrita de Rua de mão única entre 1923 e 1926, sendo publicado em livro em 1928. Rua de mão únicaé uma obra experimental que trata das principais experiências de Benjamin na República de Weimar. Utilizando o processo de montagem, bem caro ao surrealismo, o livro apresenta uma multiplicidade intercalada de temas, como a descrição de sonhos, brinquedos infantis, roupas, locais de trabalhos, postos de gasolina, prontos-socorros, primeiras leituras, a paisagem de cidades, bairros pobres, mendigos, o hábito alemão de beber cerveja, a inflação no país. Faz, portanto, um panorama da sociedade alemã no período. Por meio da crítica à situação social e intelectual da Alemanha, da montagem literária, 
dos aforismos, da inspiração na literatura popular de folhetim e, sobretudo, do caráter imagético da escrita, Rua de mão única mostra a estrutura descontínua do mundo moderno, criticando, sobretudo, a inteligência burguesa que o representava de maneira contínua e progressista. O livro de Benjamin apresenta os primeiros indícios da sua radicalização política, que será representada em seus textos posteriores, como $O$ surrealismo: o último instantâneo da inteligência europeia, $A$ obra de arte na era reprodutibilidade técnica e Sobre o conceito de História.

Outro episódio relevante na trajetória de Benjamin na década de vinte é a sua visita a Moscou em 1926-1927. Sobre esse fato, Jeanne-Marie Gagnebin, em seu livro Walter Benjamin: os cacos da história, diz:

Ele (Benjamin) passou dois meses em Moscou, de dezembro de 1926 a janeiro de 1927. Seu Diário de Moscou [...] é um documento penetrante, mas discreto, de uma tríplice dúvida: em primeiro lugar, quanto ao amor de Asja, então em convalescença após uma depressão nervosa; depois, dúvidas quanto ao futuro da URSS, e quanto às verdadeiras possibilidades de uma revolução socialista; finalmente, dúvidas quanto à competência intelectual dos funcionários dos órgãos culturais, incapazes de se posicionar clara e pessoalmente em relação, por exemplo, ao seu texto. ${ }^{3}$

A desilusão quanto à possibilidade de uma revolução socialista nos moldes da URSS e quanto à submissão do escritor ao público e aos donos do poder será determinante para Walter Benjamin. Isso pode explicar, por exemplo, a sua não militância política, e ajuda a entender as suas reflexões críticas a respeito da história e de uma possível revolução, que estão presentes nas teses Sobre o conceito de História, e também do papel do intelectual dentro do contexto revolucionário, como se pode ver no ensaio sobre o surrealismo. A singularidade do pensamento de Benjamin é definida, sobretudo, em suas principais experiências nos anos vinte e aparece, como vimos, na crítica à ideologia burguesa e também na recusa ao modelo tradicional marxista de progresso, representado pela URSS, o que vai caracterizar uma nova formade interpretar os fatos históricos, manifestada em seus principais artigos.

${ }^{3}$ GAGNEBIN, Jeanne-Marie. Walter Benjamin: os cacos da história. Tradução de Sônia Salzstein. 2‥ ed. São Paulo: Brasiliense: 1993, p.33. 
Walter Benjamin descobriu o surrealismo em uma de suas viagens a Paris. A respeito dessa descoberta, Michael Löwy diz em seu livro $A$ estrela da manhã: surrealismo e marxismo:

Fascinação é o único termo que dá conta da intensidade dos sentimentos de Walter Benjamin quando de sua descoberta do surrealismo em 19261927. Uma fascinação que se traduz inclusive em seus esforços para escapar ao envolvimento do movimento fundado por André Breton e seus amigos. ${ }^{4}$

No período em que Benjamin teve seu primeiro contato com o surrealismo, as principais obras do movimento estavam sendo publicadas, como $O$ camponês de Paris, de Aragon, em 1926, e Nadja, de Breton, em 1928. O movimento surrealista tem início com a fundação da revista Littérature por André Breton e P. Soupault em 1919 e chega a reunir muitos jovens intelectuais interessados em novas experiências de linguagem. A dita primeira fase do movimento lança as bases das experiências revolucionárias da linguagem, que estão marcadas fortemente pela influência da psicanálise de Freud. Os procedimentos de linguagem que os surrealistas utilizam concentram-se, sobretudo, na escrita automática, aquela que quer manifestar diretamente o pensamento sem a contenção estética ou moral, relatos de sonhos e acasos objetivos, ou seja, a produção de semelhanças a partir de acontecimentos que se cruzam de maneira inesperada. Dessa forma, as experiências surrealistas tentam ultrapassar a esfera do sentido e, em contato com a racionalidade do mundo moderno, ganham um efeito libertador, como mostra o Manifesto do Surrealismo, de 1924.

O surrealismo faz expandir o domínio da imaginação dentro do cotidiano da modernidade. O encantamento do surrealismo decorre desse contraste entre a expansão dos domínios da imaginação, por meio, sobretudo, de imagens que remetem ao mundo infantil e da valorização do antiquado, e o mundo burguês utilitário, o que pode explicar as distorções de suas imagens, que agregam tanto a subjetividade do sonho como a objetividade da modernidade. Esse contraste é o que possibilita o desenvolvimento do surrealismo, sobretudo em seus primeiros anos. Além da apropriação do antiquado e do sonho, o surrealismo encontra,

\footnotetext{
${ }^{4}$ LÖWY, Michael. A estrela da manhã: Surrealismo e marxismo. Tradução de Eliana Aguiar. Rio de Janeiro: Civilização Brasileira, 2002, p.39.
} 
principalmente, na força da poesia de Baudelaire, Rimbaud, Lautréamont e Apollinaire o poder de subversão e de revolta contra o mundo burguês que vai caracterizar o movimento. A força poética vinda com o surrealismo em contraste com a modernidade lembra muito oromantismo do século XIX e sobre isso Michael Löwy afirma:

O surrealismo é o exemplo mais marcante e mais fascinante de uma corrente romântica do século XX. É, dentre todos os movimentos culturais deste século, aquele que tem trazido como sua mais nobre expressão a aspiração romântica do "reencantamento" do mundo. É também aquele que encarnou de modo mais radical a dimensão revolucionária do romantismo. A revoltado espírito e a revolução social modificam a vida (Arthur Rimbaud) e transformam o mundo (Karl Marx): aliás, tais são as duas estrelas polares que orientam o movimento surrealista desde sua origem, levando à busca permanente de práticas culturais e políticas subversivas. ${ }^{5}$

Como Löwy disse, as experiências surrealistas, que lembram muito o romantismo, podem encaminhar o movimento para uma proposta de transformação política. Com a guerra da França com o Marrocos em 1925, essa possível transformação vem, efetivamente, com a militância dos principais membros do surrealismo em grupos esquerdistas, o que vai caracterizar a chamada "segunda fase" do movimento. Esse segundo momento é marcado pelo engajamento político e pela publicação do livro La Révolutionetles intellectuels do surrealista Pierre Naville em 1928, que procura conciliar as ambições surrealistas com as exigências revolucionárias do marxismo. Pode-se dizer, portanto, que o surrealismo apresenta duas fases: a primeira, que define seu primeiro programa e está muito voltada para as primeiras experiências na linguagem, e a segunda, marcada pela adesão partidária.

A primeira particularidade do ensaio de Walter Benjamin, $O$ surrealismo: 0 último instantâneo da inteligência europeia, é que ele foi escrito entre o período das primeiras experiências da linguagem e da postura extremamente rebelde dos surrealistas e a fase do engajamento político do grupo, o que, como perceberemos na análise do texto, será de grande importância. Como dissemos, a partir da crítica à

\footnotetext{
5 LÖWY, Michael. Carga explosiva: o Surrealismo como movimento romântico revolucionário. Tradução de Rodrigo Czajka. In: Temáticas. Campinas, v. 19, 2011, p. 11-24, pp . 2.
} 
inteligência burguesa e da descrença em uma possível revolução nos moldes da URSS, ou como o próprio Benjamin diz, na inteligência burguesa de esquerda, supostamente progressista, ${ }^{6}$ o ensaio do autor volta-se diretamente para a crítica a ambas através do surgimento de um movimento impactante da inteligência europeia, o surrealismo. Dessa forma, ao contrário de interpretações que apenas viam como algo efêmero ou como uma mera transposição do sonho, Benjamin interpretao surrealismo como um movimento em que a tensão revolucionária aparece na própria criação artística. A partir da análise das características revolucionárias da escrita surrealista, é possível compreender o verdadeiro alcance do movimento dentro da perspectiva do pensamento de Walter Benjamin.

\section{1. "Rua de mão única" e "O surrealismo"}

O primeiro ponto a se destacar dos primeiros parágrafos do ensaio de Benjamin sobre o surrealismo é a diferença de patamar entre a França e a Alemanha, o que propiciaria ao crítico alemão uma melhor interpretação do movimento artístico francês. Pode-se dizer que essa diferença está relacionada a uma simples distância espacial ou a referências históricas que Benjamin identificaria como sendo mais importantes em países como França e Rússia, por exemplo, a Revolução Francesa, de 1789, e a Revolução Russa, de 1917, do que na Alemanha, como a malograda revolução alemã de 1849. Em comparação com a França, o crítico vê na Alemanha um atraso de cultura política e de aprendizagem da democracia $^{7}$. Entretanto, uma melhor interpretação dessa diferença entre França e Alemanha pode ser feita relacionando o ensaio do surrealismo com a crise da economia e da crítica literária ou mesmo da intelectualidade experimentadas por Benjamin na Alemanha e apresentadas em Rua de mão única. Neste livro, Benjamin fala, dentre outras coisas, da difusão do reclame, marcado pelo olhar mercantil, em detrimento de uma verdadeira crítica, que exige certo distanciamento do objeto de análise. A partir disso, Luciano Gatti comenta:

Não é a mera distância espacial entre França e Alemanha que permite a crítica, mas um olhar distanciado sobre o seu próprio tempo, formado pela

${ }^{6}$ BENJAMIN, Walter. Magia e técnica, arte e política: ensaios sobre literatura e história da cultura. In: Obras Escolhidas I. Tradução de Sergio Paulo Rouanet. 7ª̣. ed. São Paulo: Brasiliense, 1994.pp. 29.

7 BOLLE, Willi. Fisiognomia da metrópole moderna: Representação da história em Walter Benjamin. 2a ${ }^{a}$. ed. São Paulo: EDUSP, 2000, p. 167. 
experiência da crise da crítica apresentada em Rua de mão única. Em outras palavras, trata-se de mostrarque a correta avaliação do surrealismo depende de um alinhamento com uma experiência histórica concreta e que faz jus às exigências do movimento. ${ }^{8}$

As experiências urbanas de Walter Benjamin registradas em Rua de mão únicamostram, sobretudo, a crise da inteligência alemã diante de um espaço cada vez mais marcado pelo capitalismo. Dentro dessa atmosfera é que o crítico irá interpretar omovimento surrealista, permitindo, assim, estabelecer o seu verdadeiro alcance. Isso possibilita diferenciar a abordagem de Benjamin, baseada no relato concreto da experiência urbana, das abordagens de eruditos que podem considerar o movimento surrealista apenas como um estreito riacho, alimentado pelo úmido tédio da Europa de após-guerra e pelos últimos regatos da decadência francesa e que são incapazes de determinar "as origens autênticas" do movimento. ${ }^{9}$

Uma das principais características das vanguardas artísticas do século XX é a sua vontade de romper com a estrutura da arte tradicional burguesa e atuar na vida efetiva. Dessa forma, as vanguardas artísticas, sobretudo o dadaísmo e o surrealismo, propunham-se a destruir, por meio, por exemplo, da provocação e da montagem, a arte que estivesse dissociada da vida prática. Sobre a crítica da vanguarda à arte tradicional, Peter Bürger, no livro Teoria da vanguarda, comenta:

\footnotetext{
Para os vanguardistas, a característica dominante da arte na sociedade burguesa é o seu deslocamento da práxis vital. [...]. Os vanguardistas tencionam, portanto, uma superação - no sentido hegeliano da palavra: a arte não deve simplesmente ser destruída, mas transportada para a práxis vital, onde, ainda que metamorfoseada, ela seria preservada. ${ }^{10}$
}

Essa aproximação, dita por Bürger, entre a arte e o cotidiano será decisiva para a interpretação de Benjamin sobre o surrealismo, pois estabelecerá uma relação não somente entre as características deste e a sua atuação na vida cotidiana, mas também a sua participação diante de uma práxis revolucionária. Assim, diz Benjamin:

${ }^{8}$ GATTI, Luciano. Walter Benjamin e o Surrealismo: escrita e iluminação profana. In: Arte filosofia. Ouro Preto, n. 6, 2009, p. 74-94, pp. 80.

9 BENJAMIN, 1994, p.21.

${ }^{10}$ BÜRGER, Peter. Teoria da vanguarda. Tradução de José Pedro Antunes. São Paulo: Cosac Naify, 2008, pp. 105-10 
$E$, no entanto, desde o início Breton declarou sua vontade de romper com uma prática que entrega ao público os precipitados literários de uma certa forma de existência, sem revelar essa forma. Numa formulação mais concisa e mais dialética: o domínio da literatura foi explodido de dentro, na medida em que um grupo homogêneo de homens levou a "vida literária "até os limites extremos do possível. ${ }^{11}$

A partir da tentativa de atuação das obras vanguardistas dentro da vida prática, é possível entender, de início, o caráter de revolta e de participação evocado por Breton, segundo Benjamin. A radicalização na forma artística preconizada pelas vanguardas de inícios do século $X X$ e, particularmente, pelo surrealismo, será um caminho para o engajamento político efetivo. Antes disso, porém, é necessário ver como essa tensão revolucionária está presente nas características internas da arte surrealista, que só pode ser percebida em uma situação dialética de contato com o cotidiano, como nos mostra Walter Benjamin.

\section{A iluminação profana}

Segundo Walter Benjamin em seu ensaio, O surrealismo: o último instantâneo da inteligência europeia:

$\mathrm{Na}$ estrutura do mundo, o sonho mina a individualidade, como um dente oco. Mas o processo pelo qual a embriaguez abala o Eu é ao mesmo tempo a experiência viva e fecunda que permitiu a esses homens fugir ao fascínio da embriaguez. [...]. É um grande erro supor que só podemos conhecer das "experiências surrealistas" os êxtases religiosos ou os êxtases produzidos pela droga. [...]. Porém a superação autêntica e criadora da iluminação religiosa não se dá através do narcótico. Ela se dá numa iluminação profana, de inspiração materialista e antropológica, à qual podem servir de propedêutica o haxixe, o ópio e outras drogas. ${ }^{12}$

Ao texto de Benjamin, como vemos, não interessa uma descrição pormenorizada das experiências mágicas particulares dos surrealistas no que diz respeito ao sonho ou à entorpecência. $O$ que é relevante é o contato dessas experiências com o mundo cotidiano, que possibilitará a descoberta do mágico dentro da modernidade, como diz Jeanne Marie Gagnebin em $O$ camponês de Paris: uma topografia espiritual:

\footnotetext{
${ }^{11}$ BENJAMIN, 1994, p. 22.

${ }^{12}$ BENJAMIN, 1994, p. 23.
} 
A força do surrealismo [...] não provém de uma fruição equívoca de fenômenos ocultos, de uma celebração complacente do mistério, mas, sim, contra qualquer leitura irracionalista apressada, de sua capacidade ímpar de vislumbrar o maravilhoso no coração do cotidiano [...]. ${ }^{13}$

Esse vislumbre, segundo Benjamin, não vem por meio de uma iluminação religiosa ou pela droga, mas sim pela iluminação profana, que, por isso mesmo não é mística, mas materialista, e está relacionada a uma experiência que é, sobretudo, revolucionária. A partir do exame das obras surrealistas, a característica revolucionária apontada por Benjamin ficará mais clara.

A capacidade de observar o fantástico no cotidiano é ressaltada nas duas principais obras do surrealismo, O camponês de Paris e Nadja, que tem como centro as andanças do indivíduo surrealista dentro de um grande centro urbano, Paris, que irá revelar acontecimentos inusitados e experiências mágicas, especialmente no primeiro livro. Um exemplo disso é a segunda parte de $O$ camponês de Paris, intitulada $O$ sentimento da natureza no parque Buttes-Chaumont em que o sujeito surrealista descreve a paisagem local:

\begin{abstract}
Se percorro as planícies, vejo apenas oratórios desertos, calvários derrubados. [...]. Essas Virgens, as pregas de seus vestidos supunham um processo de reflexão não compatível com o princípio de aceleração que governa hoje a passagem. [...]. Sarapintados de palavras inglesas e de palavras de criação nova, com um único braço longo e flexível, uma cabeça luminosa e sem rosto, o pé único e o ventre da roda cifrada, as bombas de gasolina têm às vezes o aspecto das divindades do Egito ou dos povoados antropófagos que adoram somente a guerra. ${ }^{14}$
\end{abstract}

As imagens formadas pelo olhar surrealista estão marcadas pela junção do primitivismo ou do infantil na descrição de objetos modernos, tornando-se a expressão de uma subjetividade que com o mundo, tornou-se estranha até diante de si mesma. ${ }^{15}$ Dessa forma, as andanças do indivíduo surrealista por Paris mostram o encanto que parecia estar perdido na modernidade. Por meio das experiências

\footnotetext{
${ }^{13}$ GAGNEBIN, Jeanne-Marie. O camponês de Paris: uma topografia espiritual. In: Sete aulas sobre linguagem, memória e história. Rio de Janeiro: Imago, 2005, p. 153-165, pp.160.

${ }^{14}$ ARAGON, Louis. $O$ camponês de Paris. Tradução de Flávia Nascimento. Rio de Janeiro: Imago, 1996 , pp. 143.

${ }^{15}$ ADORNO, Theodor W. Revendo o Surrealismo. In: Notas de Literatura I. Tradução de Jorge de Almeida. São Paulo: Duas Cidades; Editora 34, 2003, p. 135-140, pp.138.
} 
surrealistas na metrópole, a consciência burguesa, pautada no racionalismo descartiano, vai, aos poucos, sendo questionada. Em Nadja, não vemos tantas imagens mágicas como em $O$ camponês de Paris. Entretanto, o livro de Breton vai dar prioridade aos acasos objetivos, encontros casuais que mostram grandes semelhanças. Exemplo disso é o encontro dos surrealistas André Breton e Paul Éluard:

No dia da primeira representação de Couleurdutemps, de Apollinaire, no Conservatório Reneé Maubel, enquanto eu conversava no balcão com Picasso durante o intervalo, um jovem se aproximava de mim, balbucia algumas palavras e, por fim dá a entender que me havia tomado por um de seus amigos, dado como morto durante a guerra. A conversa terminou aí. Pouco tempo depois, por intermédio de Jean Paulhan, passei a me corresponder com Paul Éluard, sem que um tivesse a menor ideia da aparência física do outro. Por ocasião de uma licença, Éluard veio me visitar: tinha sido ele quem se aproximara de mim na Couleur du temps. ${ }^{16}$.

A insistência no erro ou no acaso é também uma das formas de fuga à apreensão da inteligência burguesa. Todo o livro de Breton é escrito nessa perspectiva, a trajetória de errâncias do sujeito surrealista pela cidade de Paris permite descobrir semelhanças em encontros que pareciam não corresponder, como o já citado encontro com Éluard, também com Benjamin Péret, com Nadja, com as obras de Rimbaud e com reflexões sobre Nietzsche, autores de imensa valia para os surrealistas, encontradas no velho balcão de um mercado de pulgas. ${ }^{17}$ Tanto a obra de Breton como a de Aragon nos mostram o poder do maravilhoso presente no cotidiano moderno. O que Benjamin fará, portanto, é aproximar essas experiências surrealistas na metrópole de um contexto revolucionário. Assim, aspectos da obra surrealista, como o aparecimento do mágico na realidade, a abertura da individualidade ao coletivo como um viver numa casa de vidro, ${ }^{18}$ o amor provençal e a simpatia pelo antigo, são vistos à luz de uma experiência revolucionária. Uma interpretação voltada para isso dará ao surrealismo uma grande potencialidade.

A valorização do antiquado pelos surrealistas é uma das principais características do movimento com que Benjamin mais se identifica. Nos objetos antigos e no amor provençal de Breton e Nadja, em que não há apelo sexual,

\footnotetext{
${ }^{16}$ BRETON, Andre. Nadja. Tradução de Ivo Barroso. São Paulo: Cosacnaify, 2012, p.33.

17 BRETON, 2012, p. 56.

${ }^{18}$ BENJAMIN, 1994, p.24.
} 
Benjamin encontra uma força revolucionária que está também caracterizada pela iluminação profana. A interpretação que Benjamin faz do surrealismo no que diz respeito à identificação pelo antiquado, pode ser encontrada na própria peculiaridade do seu pensamento, que, assim como os surrealistas, partilha da simpatia pelo antigo. Desde os textos sobre Baudelaire até as teses Sobre 0 conceito de história, Benjamin encontra a força revolucionária nos objetos antigos. No primeiro texto, essa vem indiretamente pela análise da poesia de Baudelaire e pela descrição das andanças deste poeta por Paris e, no segundo, de maneira direta, na crítica à historiografia tradicional, caracterizada pela valorização do progresso e pelo esquecimento dos vestígios do passado. Érica Gonçalves de Castro comenta sobre a identificação de Benjamin com o surrealismo:

O motivo de tal arrebatamento se deve ao olhar inédito que Aragon lança sobre a paisagem parisiense. Benjamin identificará nas imagens de Aragon - e, em menor escala, também no Nadja, de Breton - uma nova forma de consciência histórica. Para o pensador materialista, engajado na formação de uma nova historiografia, que desmistificasse o passado e interferisse no presente, a relação dos surrealistas com o antiquado [...] e com os objetos concretos significavam uma possibilidade de superação da realidade $[\ldots] .{ }^{19}$

O modo como Benjamin interpreta o relacionamento dos surrealistas com o passado permite colocar o surrealismo na contramão de uma posição contemplativa, que via o passado como homogêneo, bem peculiar à concepção da história tradicional. Sobre a maneira como os surrealistas enxergavam o passado, Benjamin diz: "O truque que rege esse mundo de coisas [...] consiste em trocar o olhar histórico sobre o passado por um olhar político". ${ }^{20}$ Ou seja, significa ter o passado como gerador de ação para o presente e não imóvel como a inteligência burguesa o representava. A partir disso, torna-se claro o choque que a análise de Benjamin sobre o surrealismo tem sobre o pensamento burguês. Esse choque será melhor analisado no âmbito de uma tradição esotérica, que o pensador alemão irá traçar ao longo do seu ensaio.

\section{Uma tradição esotérica}

\footnotetext{
${ }^{19}$ CASTRO, É. G. O surrealismo como construção de uma experiência histórica. In: Lettres Française. Araraquara, v. 10, 2009, p. 117-128, pp. 117.

20 BENJAMIN,1994, p. 26.
} 
A intenção de Walter Benjamin ao mencionar o desenvolvimento de uma literatura esotérica é bem clara: resgatar uma literatura potencialmente revolucionária de uma apropriação ideológica falsificadora. Como dissemos, o ensaio de Benjamin só pode ser compreendido dentro de uma vivência histórica em um determinado panorama social. Esse quadro foi representado por Benjamin em Rua de mão única e, colocando a questão diante do ensaio sobre o surrealismo, ele pode ser dito como a crise artística e intelectual contemporânea da ideologia progressista no regime social-democrata da República de Weimar. Assim, Benjamin diz:

E isso deve ser entendido, quando mais não seja, para afastar o inevitável mal entendido da "arte pela arte". Pois essa fórmula raramente foi tomada em sentido literal, quase sempre foi um simples pavilhão de conveniência, sob o qual circula uma mercadoria que não podemos declarar porque não tem nome. Seria o momento de pensar numa obra que como nenhuma outra iluminaria a crise artística, da qual somos testemunhas: uma história da literatura esotérica. ${ }^{21}$

Ao falar sobre uma literatura esotérica, Benjamin tem a intenção menos de registrar uma história da literatura à maneira tradicional do que colocar uma literatura que não se enquadra na moralidade burguesa e que, mesmo assim, está sendo colocada sobre essa moralidade pela vestimenta de uma classificação que a trata como "arte pela arte", ou seja, como mercadoria, na sua visão. Benjamin, portanto, tenta libertar o surrealismo e também autores como Apollinaire, Lautréamont, Rimbaud, Dostoiévski, Baudelaire, desse tipo de apreensão. Fazendo um paralelo entre a atuação do passado no presente de acordo com o pensamento de Benjamin, poderíamos colocar essa literatura esotérica do passado como influente no surrealismo da mesma maneira. Não é em vão que Breton reconhece, no primeiro Manifesto do Surrealismo, Apollinaire e Rimbaud como suas grandes influências.

Para entender melhor a vinculação do surrealismo com essa literatura esotérica, é necessário ver o efeito de contestação moral que essa literatura exerceu sobre a inteligência burguesa. Dessa forma, Benjamin diz:

É difícil resistir à sedução de ver o satanismo de um Rimbaud e de um Lautréamont como uma contrapartida da arte pela arte, num inventário do

${ }^{21}$ BENJAMIN, 1994, p. 27 
esnobismo. Mas, se nos decidirmos a ignorar a fachada dessa tese, encontraremos no interior algo aproveitável. Descobriremos que o culto do mal é um aparelho de desinfecção e isolamento da política, contra todo diletantismo moralizante, por mais romântico que seja esse aparelho. ${ }^{22}$

O culto do mal é um ótimo instrumento de desinfecção contra a moral burguesa, caracterizada pelo estereótipo do bem. $O$ encontro com o sujo, com o animalesco, com o doentio e com o mal, características essas presentes nas Flores do mal, de Baudelaire, na poesia de Lautréamont, nos contos de Poe e nos romances de Dostoiévski, têm o efeito de completa insubmissão à moralidade convencionalmente estabelecida, segundo Benjamin. Dentro do contexto da época, esses valores negativos reacendem uma perspectiva revolucionária diante da atmosfera otimista da social-democracia alemã. A partir disso, o pessimismo, que também é uma das características desses autores e do próprio surrealismo, terá uma importância considerável ao longo do ensaio de Benjamin.

O pessimismo está na base das características que constituem a literatura esotérica. Tanto em poetas como Apollinaire quanto nos surrealistas, o pessimismo diante do mundo moderno é o que impulsiona a revolta e o que dá potencialidade a seus textos. Benjamin interpreta esse pessimismo em contrapartida ao otimismo da social-democracia alemã e, principalmente, em contraposição à inteligência burguesa de esquerda supostamente progressista ${ }^{23}$, caracterizada pela URSS. O crítico alemão vê esses dois tipos de ideologia progressista como obstáculos ou prisões à inteligência que o surrealismo, por meio de sua força poética, vem libertar. A ideia de libertação do pensamento é muito peculiar a Benjamin em seus diversos textos, principalmente em sua visão sobre a história, esboçada nas teses Sobre $o$ conceito de história. Acerca deste último texto de Benjamin, Katia Muricy diz:

\footnotetext{
O historiador deve fazer explodir a continuidade homogênea de um tempo vazio, a linearidade do processo, e trabalhar com os fragmentos, com as ruínas do passado, cristalizados pelo olhar da atualidade, pela premência do perigo. [...]. Descontínua, anti-linear, a história em Benjamin não estabelece uma origem enquanto fundamento originário, essência, identidade ou forma imóvel a partir do qual se desenrolaria o processo.
}

\footnotetext{
${ }^{22}$ BENJAMIN, 1994, p.30.

${ }^{23}$ BENJAMIN, 1994, p. 29.
} 
Objeto de construção, a história é a perspectiva da atualidade, fixada por uma urgência guerreira. ${ }^{24}$

O pensador alemão analisa criticamente a historiografia tradicional que, sob a ótica do progresso, vislumbra a um futuro glorioso e esquece o tempo do "agora" ou da atualidade, que sempre aparece, na interpretação do crítico, como um tempo revolucionário. Fazendo um paralelo entre a interpretação de Benjamin sobre a história e sobre o surrealismo, o pessimismo pode ser visto tanto na recusa à historiografia progressista, o que culmina na libertação de um passado potencialmente revolucionário e que foi esquecido por esta, como também na recusa às ideologias progressistas tanto da direita como da esquerda política, o que tem como consequência a libertação de uma inteligência criativa e a formação de imagens do pensamento, que ganhamuma potencialidade revolucionária, como enxerga o crítico no surrealismo. Como podemosperceber, Walter Benjamin interpreta o surrealismo como algo que ultrapassa a esfera da manifestação estética e que atua diretamente no período histórico, propondo um conceito de liberdade que está associado a uma perspectiva revolucionária, como ele mesmo diz:

Desde Bakunin, não havia mais na Europa um conceito radical da liberdade. Os surrealistas dispõem desse conceito. Foram os primeiros a liquidar 0 fossilizado ideal de liberdade dos moralistas e dos humanistas, porque sabem que "a liberdade, que só pode ser adquirida neste mundo com mil sacrifícios, quer ser desfrutada, enquanto dure, em toda a sua plenitude e sem qualquer cálculo pragmático". É a prova [...] de que "a causa de libertação da humanidade, em sua forma mais simples [...], é a única pela qual vale a pena lutar". ${ }^{25}$

O crítico alemão analisa o surrealismo como algo instantâneo, ou seja, como uma explosão que abala todos os ideais conformistas de liberdade, pois quer ser desfrutada de imediato e não ser lançada a um futuro incerto. Esse conceito de liberdade, que muito está apoiada na poesia de Rimbaud e Apollinaire, lembra o anarquismo de Bakunin, como o próprio crítico pontuou. Benjamin traça uma trajetória que vai desde as relações entre as principais características do surrealismo com a realidade histórica até sua associação com uma revolução de fato, como

\footnotetext{
${ }^{24}$ MURICY, Katia. Imagens dialéticas. In: Alegorias da modernidade: imagem e pensamento em Walter Benjamin. Rio de Janeiro: Nau Editora, 2009, p. 231-260, pp. 233-234.

${ }^{25}$ BENJAMIN, 1994, p.32.
} 
mostra a sua comparação com o anarquismo. A partir daí, o ensaio em questão chega ao seu ponto culminante: como relacionar essa revolta do espírito surrealista a uma militância política de fato?

\section{Engajamento}

A questão do engajamento é um ponto crucial para o surrealismo, pois é onde o movimento sai de uma postura contemplativa para encarar uma militância política. A partir daí, o movimento surrealista se divide de fato: aqueles que não se engajam politicamente e aqueles que aderem ao Partido Comunista. O primeiro a ter uma postura militante foi Pierre Naville, autor de La Révolutionetles intellectuels, que pretende convencer seus companheiros a sair de uma visão apenas contemplativa e aderir ao comunismo. Sobre o livro de Naville, Michael Löwy comenta:

Foi durante este período, isto é, o inverno de 1925-1926, que ele (Naville)
redigiu o livrete La Révolutionetles intelectuels, que tem como objetivo
conciliar as ambições surrealistas com as exigências revolucionárias do
marxismo. O grande mérito do surrealismo era, a seu ver, seu espírito
rebelde, "inspirado pelo sentimento irredutível da liberdade" que conduz
necessariamente a um conflito com a burguesia e a uma convergência com
o movimento revolucionário. Contudo, ele proclamava seus amigos
surrealistas a irem além de um ponto puramente negativo, "metafísico" e
anarquista para adotar a abordagem dialética do comunismo, aceitando
assim a "ação disciplinada" da única via revolucionária: o marxismo. Ele
insistia na necessidade de não hesitar mais e escolher um campo:
anarquismo ou comunismo, revolução do espírito ou revolução pela
mudança do mundo dos fatos. ${ }^{26}$

O questionamento à ordem burguesa está presente no surrealismo desde seus momentos iniciais, por meio de seu espírito insubmisso e rebelde. Naville coloca a militância política como um movimento necessário a ser percorrido pela vanguarda artística, caso contrário, o surrealismo perderia sua força e ficaria como algo passageiro. Benjamin analisa, usando por base o livro de Naville, com profundidade essa relação entre o surrealismo e o engajamento político no momento em que os próprios surrealistas hesitavam com relação à militância política. $\mathrm{O}$ crítico alemão é da opinião de que não se pode sacrificar a adesão partidária pela rebeldia

\footnotetext{
${ }^{26}$ LÖWY, Michael. A estrela da manhã: Surrealismo e marxismo. Tradução de Eliana Aguiar. Rio de Janeiro: Civilização Brasileira, 2002, pp. 59-60.
} 
dos primeiros tempos, que identifica como um espírito de embriaguez necessário àpráxis revolucionária. Entretanto, privilegiar exclusivamente esse elemento é não alcançar, de fato, toda potencialidade revolucionária que o crítico encontra no surrealismo. Benjamin, portanto, não vê como o auge da energia surrealista apenas mobilizar para a prática revolucionária seu espírito de embriaguez, como uma "política poética", ${ }^{27}$ e tenta encontrar, ao longo do seu ensaio, um plano de ação que seja coerente com as características surrealistas. $O$ crítico alemão enxerga como uma ação direta e uma grande contribuição do surrealismo o desenvolvimento, no plano intelectual, de metáforas e imagens pautadas no pessimismo, que iriam de encontro às propostas otimistas da social-democracia e do socialismo soviético. Dessa forma, ele diz:

Pois o que é o programa dos partidos burgueses senão uma péssima poesia de primavera, saturada de metáforas? O socialista [...] vê "o futuro mais belo dos nossos filhos e netos" no fato de que todos agem "como se fossem anjos", todos possuem tanto "como se fossem ricos" e todos vivem "como se fossem livres". Não há nenhum vestígio real, bem entendido, de anjos, de riqueza e de liberdade. Apenas imagens. E o tesouro de imagens desses poetas da social-democracia, seu gradus ad Parnassum? 0 otimismo. $^{28}$

Assim como a inteligência burguesa age, como vimos, nas imagens, o surrealismo, em particular, e uma inteligência revolucionária, em geral, podem atuar neste campo de ação. A partir da desconfiança na metáfora moral burguesa, colocase dentro da ação política o espaço de atuação das imagens. Em outras palavras, a moral burguesa está intrincada na esfera política, impedindo, assim, qualquer tipo de ação revolucionária. A proposta dita por Benjamin é tentar extrair essa metáfora moral da esfera da ação política, e descobrir no espaço da ação política o espaço completo da imagem ${ }^{29}$. Vemos, portanto, o papel revolucionário que a imagem tem em Walter Benjamin, presente não só no texto sobre o surrealismo, mas também em outros textos posteriores, como nas teses Sobre o conceito de história. Com relação ao ensaio sobre o surrealismo, Benjamin dará grande importância às imagens como

\footnotetext{
27 BENJAMIN, 1994, p.33.

${ }^{28}$ BENJAMIN, 1994, p.33.

29 BENJAMIN, 1994, p. 34.
} 
o modo principal que permite ao artista e ao intelectual de esquerda, de modo geral, atuar revolucionariamente.

\section{Os intelectuais}

Ao vermos a importância do trabalho intelectual concedida por Benjamin ao longo do seu ensaio, remetemo-nos diretamente a sua própria vida. A tentativa de conjugar o trabalho intelectual de um aspirante a professor universitário com uma atuação política vem desde seus tempos de juventude. A partir do seu desencantamento da vida universitária, ocorrido principalmente com a recusa de sua tese à livre-docência, e de suas dúvidas quanto ao controle da cultura e do trabalho intelectual pelo regime socialista da URSS, essa tentativa de união entre o intelectual e o atuante político ganha novo fôlego, sobretudo, com o aparecimento do surrealismo. Dessa forma, Benjamin, ao falar da atividade surrealista e sua possível militância política, mostra também a sua própria condição de intelectual de origem burguesa tentando alcançar um meio de exercer uma atividade engajada politicamente dentro de suas condições. Sobre isso, o crítico Willi Bolle comenta:

[...] Benjamin teve poucas ilusões quanto aos limites impostos por uma formação e condições de vida burguesa. Jamais pretendeu transformar-se em um mestre de "arte proletária", [...]. Distanciando da estratégia da esquerda populista, viu como tarefa do escritor e artista burguês a atuação "em pontos importantes do espaço imagético". ${ }^{30}$

A melhor forma encontrada por Benjamin de trabalho do intelectual ou do artista consiste, como disse Bolle, em atuar em um espaço imagético que carrega consigo características revolucionárias. Esse espaço de imagens foi visto por Benjamin nas criações surrealistas, como a descoberta do antiquado no mais moderno, do fantástico no cotidiano, feitas a partir da experiência do individuo na metrópole, que permitiram revelar imagens carregadas de um poder revolucionário que é justamente o de ir contra a toda uma visão de mundo burguesa. Nesse espaço, é que os intelectuais devem agir, pois permite a eles uma atuação que não apenas se restringe ao conflito com a inteligência burguesa, mas também atinge a experiência cotidiana e, dessa forma, o homem comum. A partir disso, os intelectuais se colocam numa postura atuante, não contemplativa, ao contrário do

\footnotetext{
${ }^{30}$ BOLLE, Willi. Fisiognomia da metrópole moderna: Representação da história em Walter Benjamin. 2‥ ed. São Paulo: EDUSP, 2000, p.35.
} 
que acontecia com escritores soviéticos, que se tornavam especialistas em "arte proletária" e continuavam submissos ao estado populista. Assim, Benjamin desenvolve uma nova práxis revolucionária que enxerga no artista um poder mais decisivo de atuação, indo contra, portanto, ao modo como Trotski, em Literatura e Revolução, analisava o artista esquerdista, que, na sua visão, só poderia existir após uma revolução social.

As imagens ditas por Benjamin vêm, sobretudo, pelo resgate de uma memória revolucionária que foi apreendida pela moral burguesa, por isso elas têm um grande poder subversivo, capaz de reunir a criatura física a um materialismo político. A iluminação profana, que Benjamin identificou na arte surrealista, é a base de formação desses espaços de imagens. No final do ensaio, o crítico alemão compara o materialismo antropológico representado pelos surrealistas e também por outros, como Nietzsche, Rimbaud, Hegel e G. Büchner, ao materialismo metafísico de intelectuais russos, como Vogt e Bukharin, dizendo que o corpo coletivo, que para os últimos centrava-se no desenvolvimento técnico, só pode ser organizado, na sua plena eficácia política, no espaço de imagens desenvolvido pela iluminação profana, que Benjamin exemplificou com os surrealistas. Assim, o crítico alemão não enxerga eficácia política no desenvolvimento de base ou técnico como modelo principal de transformação social, mas sim na transformação das tensões revolucionárias em inervações do corpo coletivo ${ }^{31}$ e vice-versa. Nisto, os artista se intelectuais têm fundamental importância. Os surrealistas tinham sido os primeiros a percebê-lo até aquele momento.

${ }^{31}$ BENJAMIN, 1994, p.35. 


\section{BIBLIOGRAFIA}

ADORNO, Theodor W. Revendo o Surrealismo. In: Notas de Literatura I. Tradução de Jorge de Almeida. São Paulo: Duas Cidades; Editora 34, 2003, p. 135-140.

ARAGON, Louis. O camponês de Paris. Tradução de Flávia Nascimento. Rio de Janeiro: Imago, 1996.

BENJAMIN, Walter. Magia e técnica, arte e política: ensaios sobre literatura e história da cultura. In: Obras Escolhidas I. Tradução de Sergio Paulo Rouanet. 7ạ . ed. São Paulo: Brasiliense, 1994.

Rua de mão única. In: Obras Escolhidas II. Tradução de Rubens Rodrigues Filho, José Carlos Barbosa. São Paulo: Brasiliense, 1996.

BOLLE, Willi. Fisiognomia da metrópole moderna: Representação da história em Walter Benjamin. 2ª ed. São Paulo: EDUSP, 2000.

BRETON, André. Manifestos do Surrealismo. Rio de Janeiro: Nau Editora, 2001.

.Nadja. Tradução de Ivo Barroso. São Paulo: Cosacnaify, 2012.

BÜRGER, Peter. Teoria da vanguarda. Tradução de José Pedro Antunes. São Paulo: CosacNaify, 2008.

CASTRO, É. G. O surrealismo como construção de uma experiência histórica. In: Lettres Française. Araraquara, v. 10, p. 117-128, 2009.

GAGNEBIN, Jeanne Marie. O camponês de Paris: uma topografia espiritual. In: Sete aulas sobre linguagem, memória e história. Rio de Janeiro: Imago, 2005, p. 153165.

2a. ed. São Paulo: Brasiliense: 1993.

GATTI, Luciano. Walter Benjamin e o Surrealismo: escrita e iluminação profana. In: Arte filosofia. Ouro Preto, n. 6, p.74-94, 2009.

LÖWY, Michael. A estrela da manhã: Surrealismo e marxismo. Tradução de Eliana Aguiar. Rio de Janeiro: Civilização Brasileira, 2002.

. Carga explosiva: o Surrealismo como movimento romântico revolucionário. Tradução de Rodrigo Czajka. In: Temáticas. Campinas, v. 19, p. 11-24, 2011.

MURICY, Katia. Imagens dialéticas. In: Alegorias da modernidade: imagem e pensamento em Walter Benjamin. Rio de Janeiro: Nau Editora, 2009, p. 231-260. 